\section{Can microfluidics be used to create a more realistic in vitro model of the vaginal ectocervix to better understand bacterial vaginosis?}

\author{
Ashley Houlden (D) , Ruth Mackay ${ }^{2}$
}

Bacterial vaginosis (BV) is an underreported, underdiscussed and underresearched condition despite its high prevalence of $12 \%-50 \%$ worldwide. ${ }^{1} \mathrm{BV}$ is characterised by an overgrowth of anaerobic bacteria, originally attributed to Gardnerella vaginalis (GV), disrupting the typically dominant lactobacilli vaginal ecosystem, resulting in discomfort and vaginal discharge with fishy odour. Women with BV have higher risk of transmission of STI and poor perinatal outcome. ${ }^{1}$ The aetiology of $\mathrm{BV}$ remains unknown, with a large number of bacteria associated to the condition and GV presence showing variable meaning. $\mathrm{BV}$ is a multifactorial syndrome involving the interaction between the host vaginal microbial ecosystem and environmental factors. Despite treatment with metronidazole (used for the past 25 years), up to $50 \%$ of cases reoccur within 12 months.

${ }^{1}$ Biomedical Sciences, College of Health, Medicine and Life Sciences, Brunel University London, Uxbridge, UK ${ }^{2}$ Mechanical and Aerospace Engineering, College of Engineering, Design and Physical Sciences, Brunel University London, Uxbridge, UK

Correspondence to Dr Ruth Mackay, Mechanical and Aerospace Engineering, College of Engineering, Design and Physical Sciences, Brunel University London, Uxbridge UB8 3PH, UK; Ruth.MacKay@brunel.ac.uk
In vitro models have been developed, including two-dimensional, organoid and animal models; however, researchers are calling for a more representative model to investigate $\mathrm{BV}^{1}$ Over the past decade a new technology to replicate three-dimensional tissues has been established by microfluidic researchers, organ-on-a-chip (OOC). These in vitro models use microfluidic chips embedded with a scaffold and cells from specific organs. Using organspecific forces and fluidic shear flow these micro-tissues can represent the physiological environment of the organ under investigation. Numerous OOC models have been developed (lung, gut, heart and brain). OOC gut experiments have included bacterial seeding to mimic the microbiome on top of Caco- 2 cells cultured to form phenotypical intestinal villi. ${ }^{2}$ While some groups are looking at female reproductive organs, no one has developed an OOC model of the vaginal ectocervix.

$\mathrm{BV}$ is a common condition that requires greater understanding and new treatments. OOC gives researchers in the field a way forward to create a model that represents the vagina in a way not seen before.
Handling editor Prof. Anna Maria Geretti Twitter Ashley Houlden @houlden_lab

Contributors $\mathrm{AH}$ and RM both contributed equally to all aspects of the paper.

Funding The authors have not declared a specific grant for this research from any funding agency in the public, commercial or not-for-profit sectors.

Competing interests None declared.

Patient consent for publication Not required.

Provenance and peer review Not commissioned; internally peer reviewed.

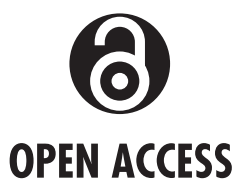

Open access This is an open access article distributed in accordance with the Creative Commons Attribution 4.0 Unported (CC BY 4.0) license, which permits others to copy, redistribute, remix, transform and build upon this work for any purpose, provided the original work is properly cited, a link to the licence is given, and indication of whether changes were made. See: https://creativecommons.org/licenses/by/ 4.0\%.

(C) Author(s) (or their employer(s)) 2022. Re-use permitted under CC BY. Published by BMJ.

Check for updates

To cite Houlden A, Mackay R. Sex Transm Infect 2022;98:74.

Published Online First 8 September 2021

Sex Transm Infect 2022;98:74.

doi:10.1136/sextrans-2021-055225

ORCID iD

Ashley Houlden http://orcid.org/0000-0002-1526-5963

\section{REFERENCES}

1 Bradshaw CS, Brotman RM. Making inroads into improving treatment of bacterial vaginosis - striving for long-term cure. BMC Infect Dis 2015;15.

$2 \mathrm{Kim} \mathrm{HJ}, \mathrm{Li} \mathrm{H}$, Collins JJ, et al. Contributions of microbiome and mechanical deformation to intestinal bacterial overgrowth and inflammation in a human guton-a-chip. Proc Natl Acad Sci U S A 2016;113:E7-15. 